V.Yu. Rozov, K.D. Kundius, D.Ye. Pelevin

\title{
ACTIVE SHIELDING OF EXTERNAL MAGNETIC FIELD OF BUILT-IN TRANSFORMER SUBSTATIONS
}

This paper deals with the mitigation of low-frequency magnetic field of build-in transformer substations down to the reference level $0.5 \mu T$ in nearby living spaces. To meet the reference level, we substantiate the actuality of the usage of active shielding methods having higher efficiency, comparably to metal consuming passive shielding. We show that the optimization of parameters and localization of compensation coils is the main goal of the synthesis of the active shielding system. The solution of synthesis problem is based on the developed $3 D$ numerical model by using particles multiswarm optimization algorithms from Pareto-optimal solutions set taking into account binary preference relations. This allows justifying the usage of simple active shielding system for magnetic field mitigation down to the reference level in living spaces, located near build-in transformer substations $(2 \times 400 \mathrm{kVA}, 6 / 0.4 \mathrm{kV})$. The synthesized active shielding system has two plane compensation coils installed near the ceiling (wall) of the substation room. The area of each coil is less than $10 \mathrm{~m}^{2}$ and the number of ampere-turns is less than 30. We show that the efficiency of the active shielding system is 6 when it electric power consumption is less than $100 \mathrm{~W}$. This allows mitigating the magnetic field down to $0.5 \mu \mathrm{T}$ in $40 \mathrm{~m}^{2}$ living space located on top or side from the substation. The application of synthesized active shielding system (subject to the positive results of experimental studies of their full-scale physical models) allows solving the actual and socially significant problem of the health protection of tenants of residential buildings with build-in transformer substations from the negative effects of power frequency magnetic field. References 16, tables 2, figures 8. Key words: urban transformer substation, living space, active shielding of the magnetic field.

Показано, що основною задачею синтезу систем активного екранування (САЕ) є оптимізація параметрів і локалізацї̈ ї компенсаційних обмоток (КО) при забезпеченні високої ефективності екранування магнітного поля (МП) трансформаторної підстанції (ТП). Ї̈ рішення виконано на основі запропонованої тривимірної комп'ютерної моделі 3 використанням алгоритмів оптимізації мультироєм частинок з множини Парето- оптимальних рішень і урахуванням бінарних відносин переваги, що дозволило обтрунтувати можливість зменшення до рівня санітарних норм індукції МП в житлових приміщеннях, розташованих поруч з ТП 6/0,4 кВ потужністю до $2 \times 400 \kappa B$, за допомогою найпростіших САЕ. Синтезована САЕ має дві плоскі КО площею до 10 м $^{2}$ при кількості ампер-витків не більще 30, що встановлюються поблизу стелі (стін) приміщення ТП, і при енергоспоживанні не більще 0,1 кВт реалізує ефективність екранування САЕ не менше 6 одиниць, що дозволяе змениити індукцію магнітного поля в розташованому зверху або збоку від ТП житловому приміщенні площею до $40 \mathrm{M}^{2}$ до рівня 0,5 мкТл. Бібл. 16, табл. 2, рис. 8.

Ключові слова: міська трансформаторна підстанція, житлове приміщення, активне екранування магнітного поля.

Показано, что основной задачей синтеза систем активного экранирования (САЭ) является оптимизация параметров и локализации их компенсационных обмоток (КО) при обеспечении высокой эффективности экранирования магнитного поля (МП) трансформаторной подстанции (ТП). Ее решение выполнено на основе предложенной трехмерной компьютерной модели с использованием алгоритмов оптимизации мультироем частиц из множества Парето-оптимальных решений с учетом бинарных отночений предпочтения, что позволило обосновать возможность уменьшения до уровня санитарных норм индукции МП в жилых помещениях, расположенных рядом с ТП 6/0,4 кВ мощностью до $2 \times 400$ кВА, с помощью простейших САЭ. Синтезированная САЭ имеет две устанавливаемые вблизи потолка (стен) помещения ТП плоские КО площадью до $10 \mathrm{M}^{2}$ при количестве ампер-витков не более 30, и при энергопотреблении не более 0,1 кВт реализует эффективность экранирования САЭ не менее 6 единиц, что позволяет уменьшить индукцию магнитного поля в расположенном сверху либо сбоку от ТП жсилом помещении площадью до $40 \boldsymbol{м}^{2}$ до уровня 0,5 мкТл. Библ. 16, табл. 2, рис. 8.

Ключевые слова: городская трансформаторная подстанция, жилое помещение, активное экранирование магнитного поля.

Introduction. Much attention is paid to the problem of protecting the living environment from the influence of the magnetic field (MF) of electric power facilities around the world, since power frequency $(50-60 \mathrm{~Hz}) \mathrm{MF}$ is dangerous to human health even with its weak but prolonged exposure $[1,2]$. The main sources of MF in a residential environment are overhead and cable power lines (PLs) located in residential areas, as well as urban transformer substations (TSs) [3].

Urban TSs are located in separate buildings or are built into residential buildings [3]. The most acute problem of reducing external MF of the TS is in residential buildings with built-in TS [2-4], when the distance between the TS and residential premises is reduced to several meters. Such buildings (Fig. 1) are quite widespread in Ukraine and other countries.

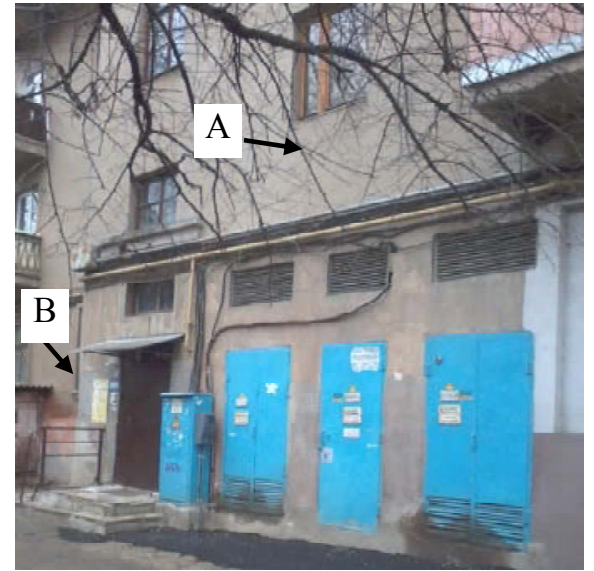

Fig. 1. Typical residential building in Kharkiv with built-in TP (c) V.Yu. Rozov, K.D. Kundius, D.Ye. Pelevin 
In addition, built-in TPs began to be widely used in the world in modern ultra-high-rise residential buildings for individual high voltage power supply of sections of several tens of floors in order to reduce electricity losses $[5,6]$.

The studies conducted by the authors [3] show that the external MF of typical built-in TSs with power of $400(800) \mathrm{kVA}$ can exceed the level of sanitary standards in residential premises adjacent to the transformer substation by 3-10 times, which requires measures to reduce their MF. In this case, the main source of the external TS MF is their current leads, and the scattering MF of TS transformers at distances greater than $2 \mathrm{~m}$ from the transformer substation can be neglected [3].

The most urgent problem is the reduction of the TS MF in old buildings with built-in TS (Fig. 1), when the practical use of methods to reduce MF due to the improvement of the design of TS [3] is difficult. Currently, the most common technique in practice of reducing the $\mathrm{MF}$ in the spaces adjacent to the TS is passive shielding of the walls (ceilings) of the TS premises by electromagnetic (magnetostatic) shields [7]. However, this shielding method for low-frequency TS MF is characterized by high metal consumption and cost at low efficiency.

Therefore, a promising method of reducing the TS $\mathrm{MF}$ is active shielding (compensation) of the MF [3, 8-14]. Moreover, the global trend in the development of active shielding systems (ASS) aims to optimize their design for energy consumption and cost, provided that the necessary shielding efficiency is provided.

However, in Ukraine, the development of methods and means of active shielding of TS MF is not given due attention. So, up to the present, the possibility and the ways to create inexpensive budgetary ASSs with efficiency sufficient to reduce the TS MF in nearby residential premises to the level of sanitary standards have not been substantiated.

The goal of the work is an analysis of the possibility of reducing the magnetic flux density in residential premises located next to urban transformer substations to the level of sanitary standards using simple active shielding systems.

By the simplest ASS we mean a system with a minimum number of flat compensation windings (CWs) placed near the surface of the walls (floors) of the premises, which has a limited power consumption of hundreds of watts.

Active shielding method. The method of active shielding of the potential TS $M$ in the volume of the living premise adjacent to the TS is realized through the formation of the ASS (Fig. 2) of the compensating MF of such a spatio-temporal structure, the superposition of which with the original TS MF reduces the effective value of the magnetic flux density in the entire protected volume of the living space from walls and floor to a distance of more than $0.5 \mathrm{~m}$, to the level of sanitary standards $(0.5 \mu \mathrm{T})$ for the population [12]. In this case, the compensating MF generated by the $\mathrm{CW}$ must also be potential in the volume of the living space, which imposes certain requirements on the configuration and location coordinates of the $\mathrm{CW}$ during their synthesis.

ASS (Fig. 2) consists of the following main elements: compensation windings $(\mathrm{CW})$; regulated power source (PS) performing the function of a power amplifier, control system (CS); sensors (S) of current or MF. In the general case, ASS can have a different amount of CW, S and can be realized in a closed or open structure $[11,12]$.

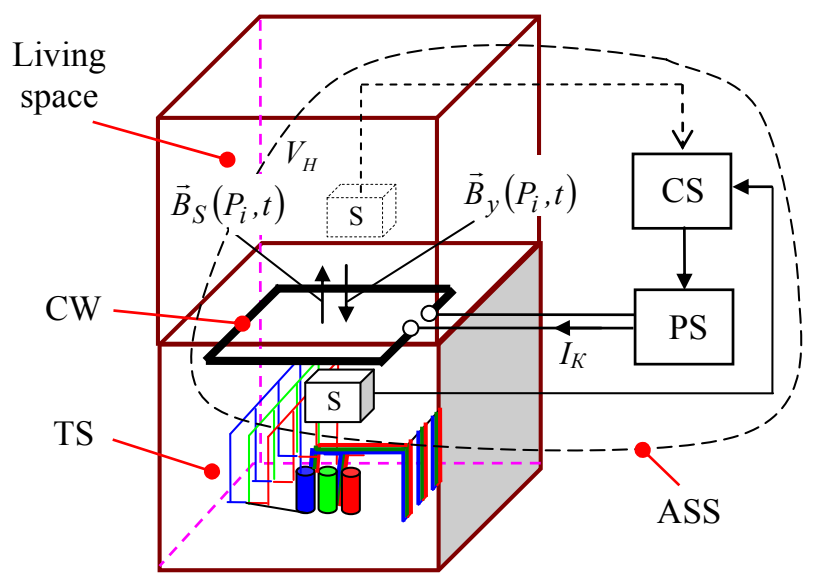

Fig. 2. Active shielding of the external TS MF

To determine the parameters of the ASS (Fig. 2), it is necessary to carry out its synthesis. The initial data for the synthesis of ASS are: the spatio-temporal characteristic of the initial MF of the urban TS in the protected volume (residential space); mutual spatial arrangement of active elements of the TS and residential premises; geometry and number of three-phase current leads of the TS; the standard value of the level of the magnetic flux density, which should be achieved as a result of shielding. In this case, the effect of shielding of the TS MF by the walls and floors of residential buildings is neglected due to its smallness $[15,16]$.

We carry out active shielding of TS MF using the proposed in [14] method of synthesis of ASS, created for shielding of the MF of high-voltage PLs in order to reduce it to a level safe for the population in nearby residential buildings. A feature of this method is the solution of the shielding problem in a $2 \mathrm{D}$ formulation, which is acceptable for extended PLs with an almost zero component of magnetic flux density directed along the PL, which allows to significantly simplify the solution to the synthesis problem for such ASS [13, 14].

A more complicated design of current leads of finite length [3], compared with PL [3], makes it necessary to model the TS MF in a 3D formulation, which significantly complicates the synthesis of the TS ASS. Another feature of solving the problem of synthesis of the TS ASS is the need to locate their CW outside residential premises. Taking into account these features, the synthesis of TS MF ASS is carried out on the basis of the modified method developed and presented below.

A modified method for the synthesis of TS ASS. The mathematical model of the initial external TS MF in 
the shielding zone (residential space), remote from the TS by more than 2 meters [3], not containing ferromagnetic elements and magnetic field sources, can be represented as:

$$
\begin{aligned}
& \vec{B}_{S}\left(P_{i}, t\right)=-\sum_{k=1}^{K} \sum_{\alpha=1}^{3} \sum_{n=1}^{N} \nabla\left[\frac{\mu_{0}\left(\vec{m}(t)_{l \alpha n}, \vec{R}_{l \alpha i}\right)}{4 \pi R_{l \alpha i}^{3}}\right] ; \\
& \vec{m}(t)_{l \alpha n}=I(t) \cdot \vec{S}_{l \alpha n},
\end{aligned}
$$

where $N$ is the number of microcontours in the rectilinear contour of the TS current lead; $k$ is the number of rectilinear contours; $\vec{S}_{l \alpha n}$ is the area vector of the microcontour; $\vec{n}_{i}$ is the unit vector normal to $S_{i} ; \vec{R}_{l \alpha i}$ is the radius vector from the geometric center of the microcontour to the observation point $P_{i} ; I(t)$ is the instantaneous value of the microcontour current; $\alpha$ is the phase number of the TS current lead $(\alpha=1 \ldots, 3) ; \mu_{0}$ is the magnetic constant. In accordance with (1), the TS MF is potential and decreases with distance from the source.

Let us introduce the vector of the sought-for parameters $R$, the components of which are the sought-for geometrical parameters, the coordinates of the spatial arrangement of the ASS CWs and the sought-for parameters of the ASS CWs. Then, the flux density of the resulting potential MF generated by the TS current leads and ASS is determined as

$$
\vec{B}\left(R, P_{i}, t\right)=\vec{B}_{S}\left(P_{i}, t\right)+\vec{B}_{y}\left(R, P_{i}, t\right),
$$

where $\vec{B}_{y}\left(R, P_{i}, t\right)$ are the instantaneous values of the flux density of the MF generated by the ASS CWs in points $P_{i}$.

By analogy with [14], we reduce the determination of the vector of the sought-for parameters $R$ to the solution of the multicriteria optimization problem of the vector criterion

$$
B(R)=\left[B\left(R, P_{1}\right), B\left(R, P_{2}\right) \ldots B\left(R, P_{m}\right)\right]^{T},
$$

whose components $\vec{B}\left(R, P_{i}\right)$ are the values of the flux density of the resulting MF at points $P_{i}$.

This multicriteria optimization problem (3) will be solved in computer modelling based on algorithms for optimizing by particles multiswarm from the set of Pareto-optimal solutions taking into account binary preference relations [13, 14]. Modelling is carried out in the MATLAB software package.

Analysis of the effectiveness of active shielding of the TS MF. The efficiency (factor) of the shielding of the ASS MF at the point $P_{i}$ in accordance with [11] can be determined by the relation

$$
E_{P i}=\frac{\left|\vec{B}_{S}\left(P_{i}\right)\right|}{\left|\vec{B}_{S}\left(P_{i}\right)+\vec{B}_{y}\left(P_{i}\right)\right|}=\frac{1}{\delta_{P i}},
$$

where $\vec{B}_{S}\left(P_{i}\right), \vec{B}_{y}\left(P_{i}\right)$ are the effective values of the initial and generated by ASS magnetic flux densities at the point $P_{i} ; \delta_{P i}$ is the relative error in the shielding of the ASS.
For example, with the above-mentioned excess of sanitary standards by 3-10 times, the required shielding efficiency will be 3 (10) units, and the permissible relative error in compensating the magnetic flux density should be no less than $0.33(0.1)$, respectively. Here, the value $\delta_{P i}$ can be defined as

$$
\delta_{P i}=\sqrt{\delta_{\text {Pim }}^{2}+\delta_{\text {Pir }}^{2}},
$$

where $\delta_{\text {Pim }}$ is the relative methodological error of the ASS, determined by the mismatch of the spatial structure of the initial MF and the compensating MF generated by the CWs; $\delta_{\text {Pir }}$ is the relative error of regulation of the ASS.

An analysis of relation (5) shows that the main component of the ASS error is the methodological error $\delta_{\text {Pim }}$, which is determined by the $\mathrm{CW}$ parameters and limited to 0.1 with shielding efficiency of no more than 10 units. In this case, the relative error $\delta_{\text {Pir }}$ of regulation of the ASS when using modern automatic control systems can be easily reduced to values of 0.01-0.03, at which it will not have a significant impact on the total shielding error of $\delta_{P i}$ of the ASS. This allows at this stage to reduce the synthesis of ASS to the synthesis of its CWs. Therefore, the ASS control algorithm is not considered in this paper and is the subject of separate studies.

We carry out the solution of the problem of synthesis of ASS CWs and analysis of the efficiency of shielding of TS MF for a typical urban two-transformer substation $(2 \times 400 \mathrm{kVA}, 6 / 0.4 \mathrm{kV})$, built into a residential building on the ground floor. The dimensions of the TS premises correspond to the sizes of neighboring residential premises. The arrangement of TS current leads is shown in Fig. 3, and their geometry is given in [3]. Three-phase current leads are connected with direct phase sequence.

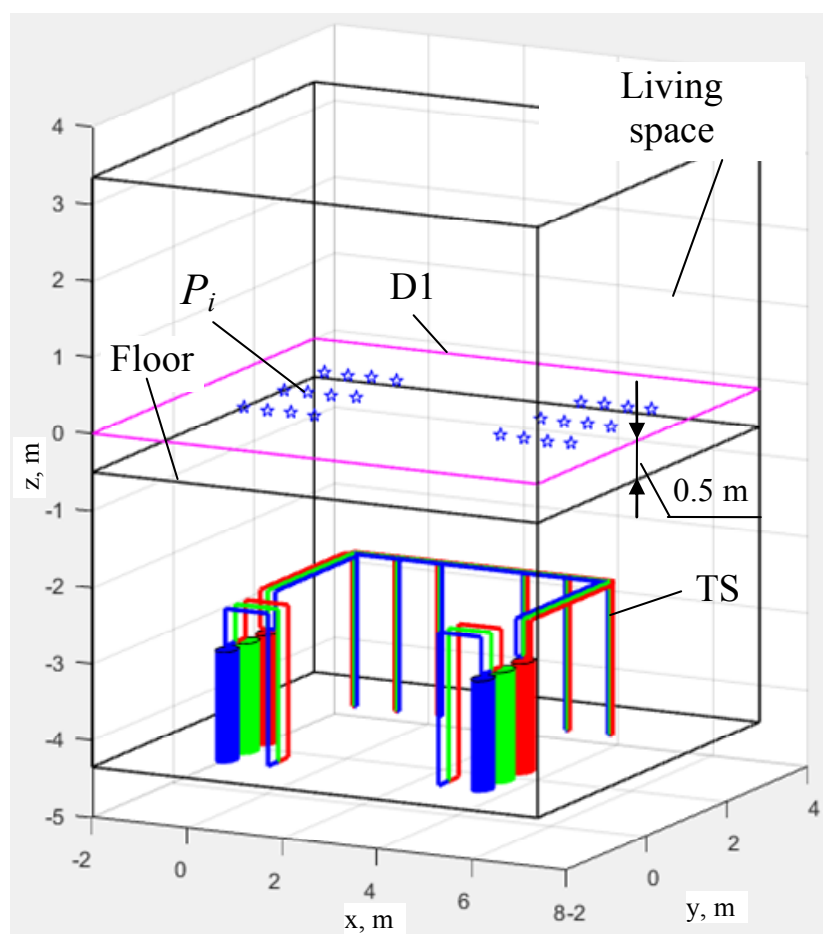

Fig. 3. Location of the premise over the TS (option A) 
Computer simulation of the external $\mathrm{TS} \mathrm{MF}$ is carried out in accordance with (1)-(3). In this case, two options for the location of the living space relative to the TS are considered (Fig. 1): option A - the premise is located over the TS; option B - the premise is located near the TS on one floor (on the side of the TS).

Shielding of the MF in the premise over the TS (option A). Let us carry out the synthesis of ASS CWs, which ensure the necessary efficiency of the MF shielding in the premise located over the TS (Fig. 3).

To guarantee a decrease in the flux density of the potential MF to the level of sanitary standards in the entire living space, it is enough to ensure a corresponding decrease in the MF on the control plane D1, which is $0.5 \mathrm{~m}$ from the floor of the room (Fig. 3), where the MF is normalized $[1,2]$.

The calculated value of the flux density of the initial TS MF at rated power of the TS is presented in Fig. 4. Here, the maximum value of the initial magnetic flux density is $3 \mu \mathrm{T}$, which is 6 times higher than the level of sanitary standards of $0.5 \mu \mathrm{T}[2]$.
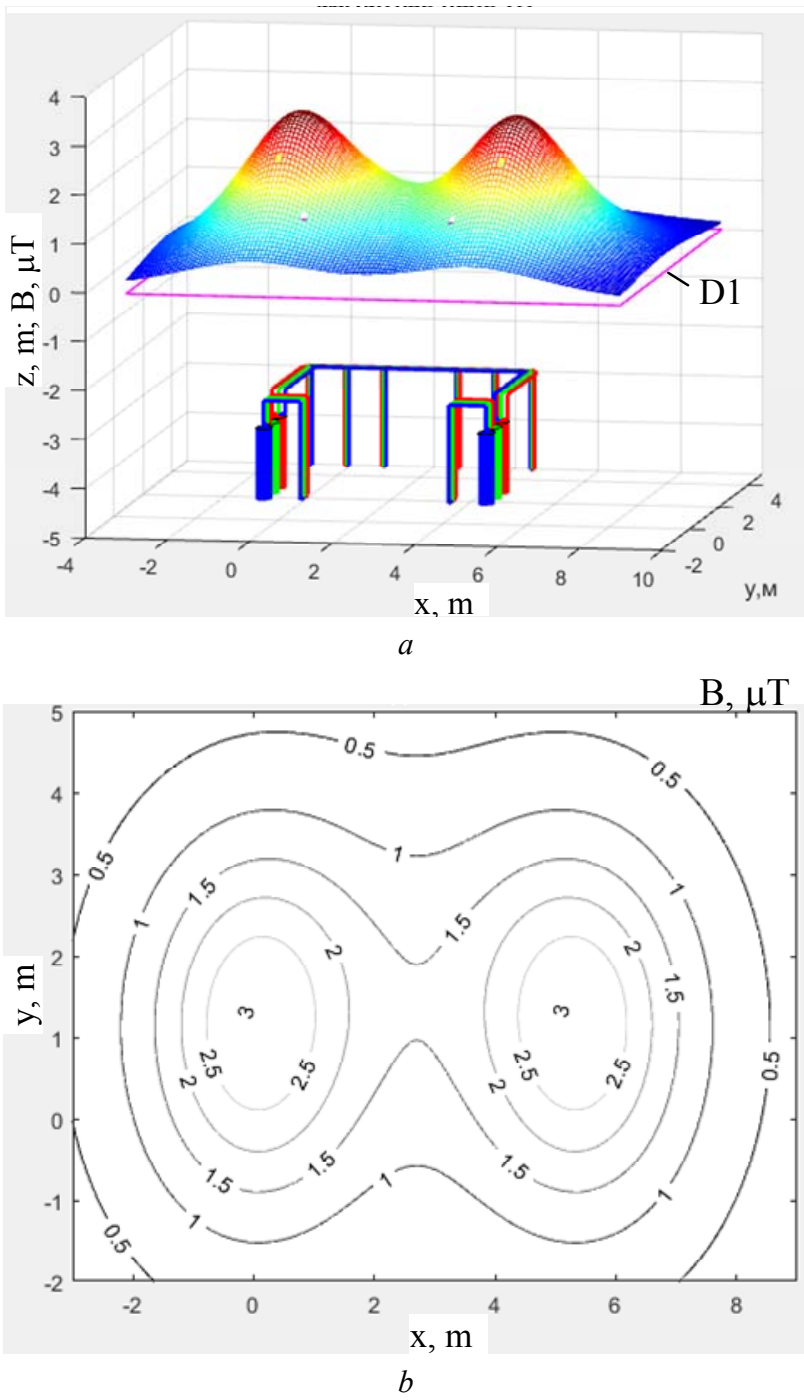

Fig. 4. Distribution of the initial magnetic flux density in the living space over the TS, option A:

(a) - indoors; $(b)$ - on the control plane D1
Based on the simulation, synthesis of the ASS CWs is performed (Fig. 5), and their parameters are determined in accordance with Table 1. CWs are located in the TS premise, parallel to its ceiling, at a distance of $0.55 \mathrm{~m}$ from it, and make it possible to realize the necessary shielding efficiency, reducing the initial TS MF (Fig. 4) to the level of sanitary standards.
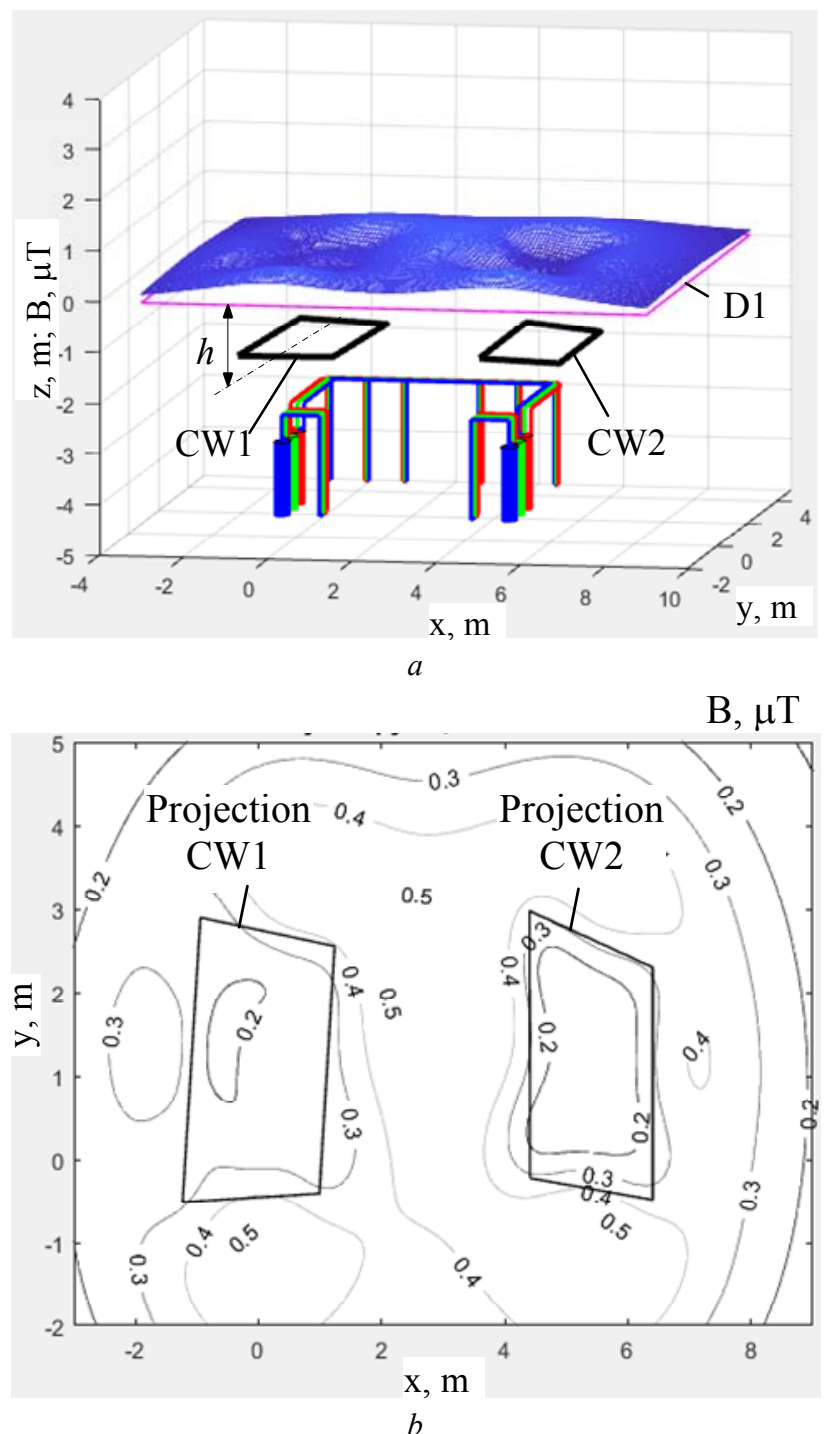

Fig. 5. Distribution of the resulting magnetic flux density in the living space over the TS using ASS, option A: (a) - indoors; $(b)$ - on the control plane D1

Table 1

Parameters of compensating windings of the ASS (option A)

\begin{tabular}{|c|c|c|}
\hline $\begin{array}{l}\text { CW } \\
\text { No. }\end{array}$ & $\begin{array}{l}\text { Ampere-turns, } \\
\text { CW power }\end{array}$ & $\mathrm{CW}$ coordinates \\
\hline 1 & $\begin{array}{l}I W 1=24,5 \mathrm{~A} \\
S=36 \mathrm{VA} \\
h=1,35 \mathrm{~m}\end{array}$ & $\begin{array}{l}x 11=-1,23 \mathrm{~m}, \quad y 11=-0,51 \mathrm{~m}, \\
z 11=-1,35 \mathrm{~m}, x 12=-0,94 \mathrm{~m}, \\
y 12=2,90 \mathrm{~m}, z 12=-1,35 \mathrm{~m}, \\
x 13=1,24 \mathrm{~m}, \quad y 13=2,55 \mathrm{~m}, \\
z 13=-1,35 \mathrm{~m}, x 14=0,99 \mathrm{~m}, \\
y 14=-0,40 \mathrm{~m}, \quad z 14=-1,35 \mathrm{~m} .\end{array}$ \\
\hline 2 & $\begin{array}{l}I W 2=25,6 \text { A } \\
S=36 \mathrm{VA} \\
h=1,35 \mathrm{~m}\end{array}$ & $\begin{array}{l}x 21=4,41 \mathrm{~m}, \quad y 21=-0,22 \mathrm{~m}, \\
z 21=-1,35 \mathrm{~m}, x 22=4,40 \mathrm{~m} \\
y 22=2,98 \mathrm{~m}, \quad z 22=-1,35 \mathrm{~m}, \\
x 23=6,40 \mathrm{~m}, \quad y 23=2,30 \mathrm{~m} \\
z 23=-1,35 \mathrm{~m}, x 24=6,40 \mathrm{~m} \\
y 24=-0,48 \mathrm{~m}, \quad z 24=-1,35 \mathrm{~m}\end{array}$ \\
\hline
\end{tabular}


As the simulation results show (Fig. 5), when using synthesized ASS, the level of the magnetic flux density both on the D1 plane and in the entire living space decreases to the safe value of $0.5 \mu \mathrm{T}$. Here, the synthesized ASS has a minimum number of CWs located in the TS premise and provides the necessary shielding efficiency (at least 6 units) with energy consumption of not more than $0.1 \mathrm{~kW}$.

Shielding of the MF in the premise located near the TP (option B). Let us perform the synthesis of ASS CWs, providing the necessary efficiency of shielding of the MF in the premise located near the TS on the same floor (Fig. 6).

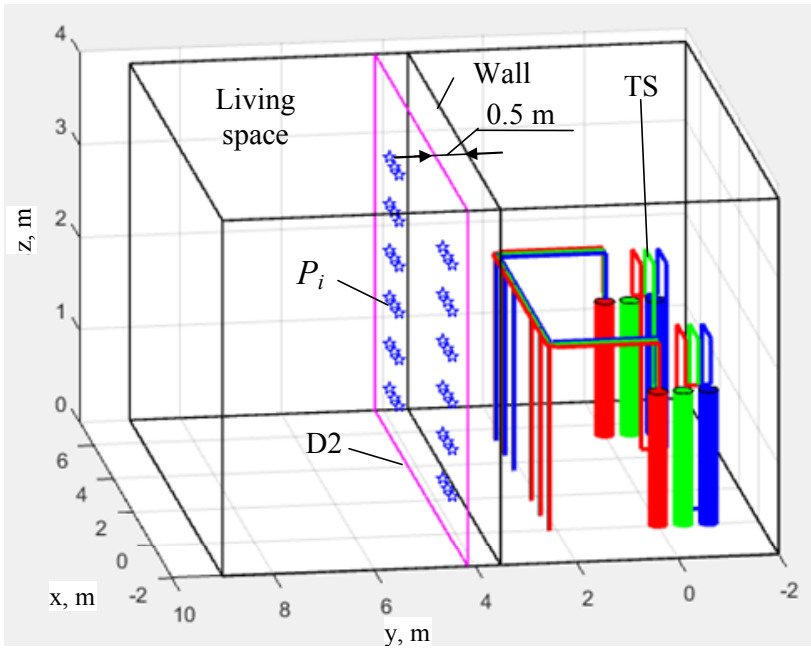

Fig. 6. The location of the premise on the side of the TS (option B)

Figure 7 shows the calculated value of the flux density of the initial TS MF, which reaches $1.2 \mu \mathrm{T}$, which is 2.4 times higher than the sanitary standards of $0.5 \mu \mathrm{T}$.

$\mathrm{B}, \mu \mathrm{T}$

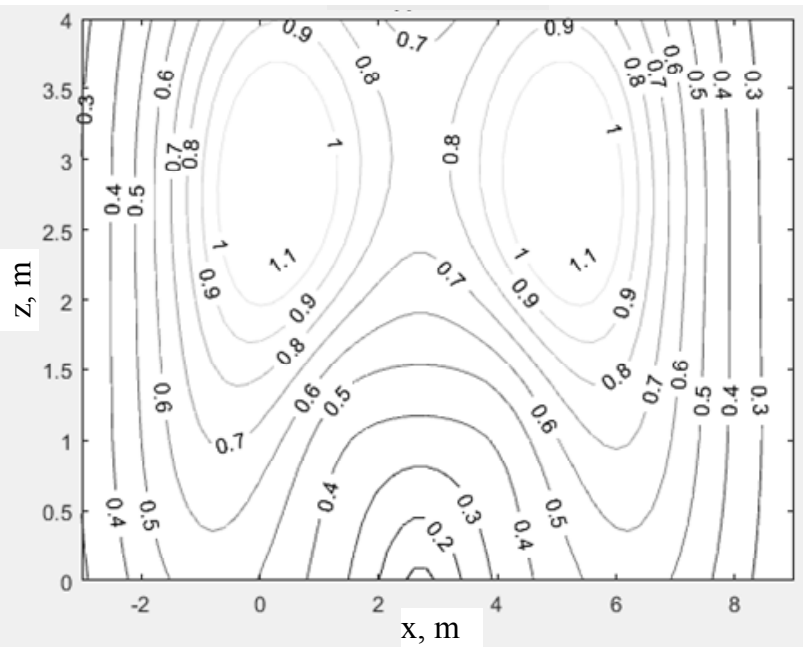

Fig. 7. Distribution of the initial magnetic flux density in the living space located on the side of the TS, option B, on the $\mathrm{D} 2$ plane, $0.5 \mathrm{~m}$ from the room wall

Based on the simulation, the synthesis of the ASS CWs (Fig. 8) located at a distance of $0.35 \mathrm{~m}$ from the plane of the wall of the TS premise is performed, allowing to realize the necessary shielding efficiency and reduce the flux density of the initial TS MF (Fig. 7) to the level of sanitary standards $(0.5 \mu \mathrm{T})$ when using CWs with parameters in accordance with Table 2.

Table 2

Parameters of compensating windings of the ASS (option B)

\begin{tabular}{|c|c|c|}
\hline CW No. & $\begin{array}{l}\text { Ampere-turns, } \\
\text { CW power }\end{array}$ & $\mathrm{CW}$ coordinates \\
\hline 1 & $\begin{array}{l}I W 1=9,45 \mathrm{~A} \\
S=10 \mathrm{VA} \\
h=1,15 \mathrm{~m}\end{array}$ & $\begin{array}{l}x 11=-1,42 \mathrm{~m}, \quad y 11=3,0 \mathrm{~m} \\
z 11=2,50 \mathrm{~m}, \quad x 12=-2,0 \mathrm{~m}, \\
y 12=3,0 \mathrm{~m}, \quad z 12=3,70 \mathrm{~m}, \\
x 13=2,0 \mathrm{~m}, \quad y 13=3,0 \mathrm{~m}, \\
z 13=3,70 \mathrm{~m}, \quad x 14=2,0 \mathrm{~m}, \\
y 14=3,0 \mathrm{~m}, \quad z 14=1,28 \mathrm{~m} .\end{array}$ \\
\hline 2 & $\begin{array}{l}I W 2=9,44 \mathrm{~A} \\
S=10 \mathrm{VA} \\
h=1,15 \mathrm{~m} .\end{array}$ & $\begin{array}{l}x 21=3,47 \mathrm{~m}, \quad y 21=3,0 \mathrm{~m}, \\
z 21=1,11 \mathrm{M}, \quad x 22=3,74 \mathrm{~m}, \\
y 22=3,0 \mathrm{~m}, \quad z 22=3,70 \mathrm{~m}, \\
x 23=7,40 \mathrm{~m}, \quad y 23=3,0 \mathrm{~m}, \\
z 23=3,70 \mathrm{~m}, \quad x 24=6,56 \mathrm{~m}, \\
y 24=3,0 \mathrm{~m}, \quad z 24=2,40 \mathrm{~m} .\end{array}$ \\
\hline
\end{tabular}

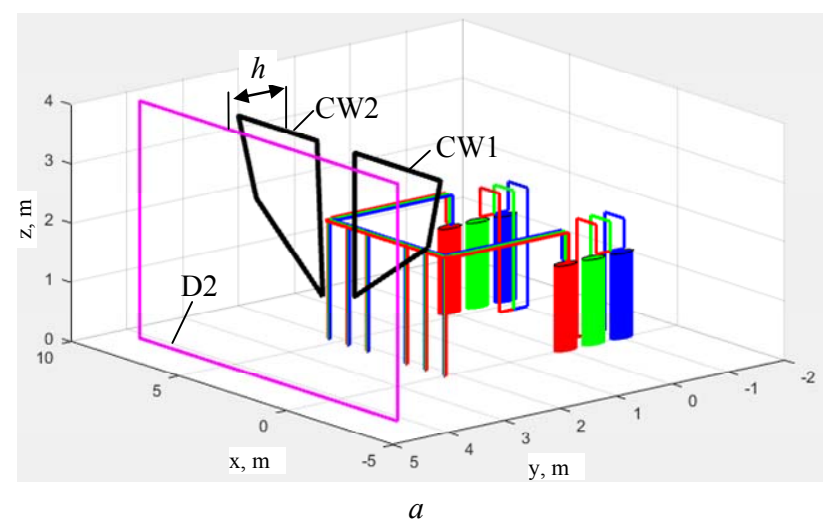

$\mathrm{B}, \mu \mathrm{T}$

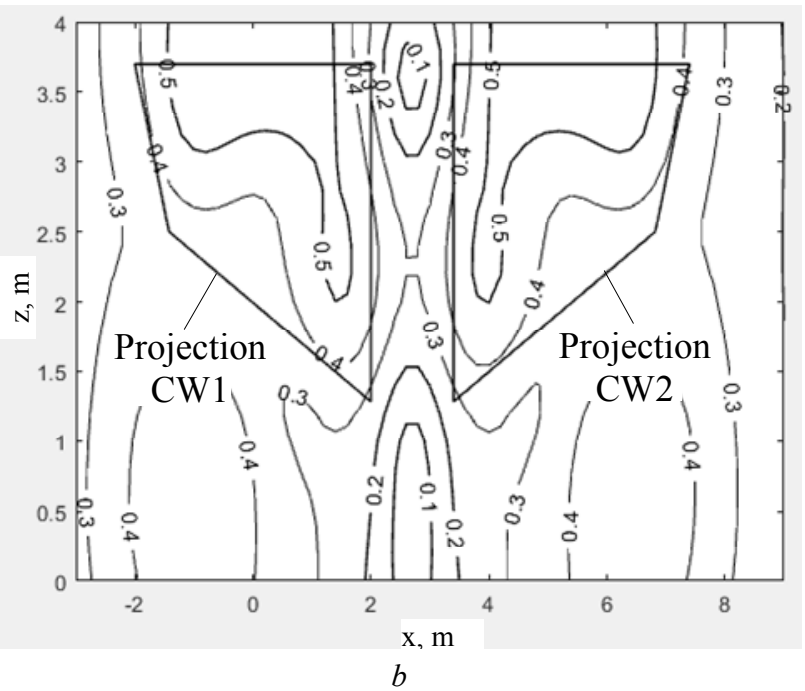

Fig. 8. Distribution of the resulting magnetic flux density in the living space on the side of the TS when using the ASS, option B: $(a)$ - position of CWs and TS; $(b)-$ MF on the control plane D2

The layout of the ASS CWs is shown in Fig. 8, $a$ and the calculated distribution of the resulting magnetic flux 
density in the living space on the side of the TS when using the ASS (option B) on the control plane D2 of the premise wall is shown in Fig. 8,b.

As the simulation results show (Fig. 8), when using synthesized ASS, the level of the magnetic flux density in the volume of the living space decreases to the safe value of $0.5 \mu \mathrm{T}$. Here, the synthesized ASS also has a minimum number of CWs located near the plane of the wall of the TS premise and provides the necessary shielding efficiency (at least 2.4 units) with energy consumption of not more than $0.03 \mathrm{~kW}$.

Thus, the above analysis confirms the possibility of reducing the magnetic flux density in residential premises with area of $40 \mathrm{~m}^{2}$, located near urban transformer substations $2 \times 400 \mathrm{kVA}, 6 / 0.4 \mathrm{kV}$, to the level of sanitary standards with the help of simplest ASS with two flat compensation windings placed near the floor (wall) of the premises of the TS. Here, the energy consumption of the ASS is no more than $0.1 \mathrm{~kW}$, the CW area is no more than $10 \mathrm{~m}^{2}$ with the number of $\mathrm{CW}$ ampere-turns no more than 30 . The shielding efficiency (factor) realized by the synthesized TS ASS (Fig. 2) reaches more than 6 units, which has experimental confirmation in laboratory conditions.

At the next stages of creating the TS MF ASS, it is planned to develop its structural elements (Fig. 2) and conduct experimental studies of full-scale models of the ASS in residential buildings with built-in TS.

\section{Conclusions.}

1. For the first time, the possibility of solving the problem of reducing to the level of sanitary norms of the magnetic flux density in a living space located near an urban transformer substation with power of up to $2 \times 400 \mathrm{kVA}$ using the simplest active shielding systems has been substantiated. The justification is carried out in computer simulation using algorithms for optimization of particles multiswarm from a multitude of Pareto-optimal solutions taking into account binary preference relations.

2. The synthesis of the simplest systems of active shielding of the magnetic field of transformer substations with two flat compensation windings located near the ceiling (walls) of the TS premise and allowing the magnetic field to be reduced to the level of sanitary standards in a nearby residential area of up to $40 \mathrm{~m}^{2}$ is performed. In this case, the energy consumption of the active shielding system is no more than $0.1 \mathrm{~kW}$, the area of the compensation windings is no more than $10 \mathrm{~m}^{2}$ with the number of ampere-turns no more than 30 , and the shielding efficiency (factor) reaches more than 6 units, which has experimental confirmation in laboratory conditions.

3. The practical use of synthesized active shielding systems, subject to the positive results of experimental studies of their full-scale physical models, will effectively solve the urgent and socially significant task of protecting the health of the population of residential buildings with built-in transformer substations from the negative effects of magnetic fields of power frequency.

\section{REFERENCES}

1. Serdiuk A.M., Dumanskiy V.Yu., Bitkin S.V., Didyk N.V., Dumanskiy Yu.D. Hygienical ground of requirements to placing and exploitation of cable busses of electricity transmission and their equipment in the conditions of modern municipal building. Hygiene of populated places, 2015, no.66, pp. 20-29. (Ukr).

2. Pravila ulashtuvannya electroustanovok [Electrical installation regulations]. Kharkiv, Fort Publ., 2017. 760 p. (Ukr).

3. Rozov V.Yu., Pelevin D.Ye., Pielievina K.D. External magnetic field of urban transformer substations and methods of its normalization. Electrical engineering \& electromechanics, 2017, no.5, pp. 60-66. doi: 10.20998/2074-272X.2017.5.10.

4. Opoleva G.N. Skhemy i podstantsii elektrosnabzheniia. Spravochnik [Schemes and substations of power supply. Directory]. Moscow, Forum-Infra Publ., 2006. 480 p. (Rus).

5. Leung S.W., Chan K.H., Fung L.C. Investigation of power frequency magnetic field radiation in typical high-rise building. European Transactions on Electrical Power, 2011, vol. 21, no. 5, pp. 1711-1718. doi: 10.1002/etep.517.

6. Rahman N.A., Rashid N.A., Mahadi W.N., Rasol Z. Magnetic field exposure assessment of electric power substation in high rise building. Journal of Applied Sciences, 2011, vol. 11, pp. 953-961. doi: 10.3923/jas.2011.953.961.

7. Grbić M., Canova A., Giaccone L. Magnetic field in an apartment located above 10/0.4 kV substation: levels and mitigation techniques. CIRED - Open Access Proceedings Journal, 2017, vol. 2017, no. 1, pp. 752-756. doi: 10.1049/oapcired.2017.1230.

8. Bravo-Rodríguez J., del-Pino-López J., Cruz-Romero P. A Survey on Optimization Techniques Applied to Magnetic Field Mitigation in Power Systems. Energies, 2019, vol. 12, no. 7, p. 1332. doi: 10.3390/en12071332

9. Canova A., Giaccone L. Real-time optimization of active loops for the magnetic field minimization. International Journal of Applied Electromagnetics and Mechanics, 2018, vol.56, pp. 97-106. doi: 10.3233/jae-172286.

10. del Pino Lopez J.C., Giaccone L., Canova A., Cruz Romero P. Ga-based active loop optimization for magnetic field mitigation of $\mathrm{MV} / \mathrm{LV}$ substations. IEEE Latin America Transactions, 2014, vol.12, no.6, pp. 1055-1061. doi: 10.1109/tla.2014.6894000.

11. Shydlovskyi A.K., Rozov V.Yu. The system of automatic compensation of external magnetic fields of energy-objects. Technical electrodynamics, 1996, no.1, pp. 3-9. (Rus).

12. Rozov V.Yu., Rezinkina M.M., Dumanskiy Yu.D., Gvozdenko L.A. The study of man-caused distortions in the geomagnetic field of residential and industrial buildings and to identify ways to reduce them to a safe level. Technical electrodynamics. Thematic issue "Problems of modern electrical engineering». 2008, chapter 2, pp. 3-8. (Rus).

13. Kuznetsov B.I., Nikitina T.B., Bovdui I.V. High voltage power lines magnetic field system of active shielding with compensation coil different spatial arrangement. Electrical engineering \& electromechanics, 2019, no.4, pp. 17-25. doi: 10.20998/2074-272X.2019.4.03.

14. Kuznetsov B.I., Nikitina T.B., Bovdui I.V. Active shielding of power frequency magnetic field in buildings in 
the vicinity of the electric airlines. Problemele energeticii regionale, 2019, no. 1-1(40), pp. 11-24. doi: 10.5281/zenodo.3239130.

15. Rozov V.Yu., Grinchenko V.S., Pelevin D.Ye., Chunikhin K.V. Simulation of electromagnetic field in residential buildings located near overhead lines. Technical Electrodynamics, 2016, no. 3, pp. 6-8. (Rus). doi: 10.15407/techned2016.03.006.

16. Pelevin D.Ye Screening magnetic fields of the power frequency by the walls of houses. Electrical engineering \& electromechanics, 2015, no. 4, pp. 53-55. (Rus). doi: 10.20998/2074-272X.2015.4.10.

\section{Received 04.05.2020}

How to cite this article:

Rozov V.Yu., Kundius K.D., Pelevin D.Ye. Active shielding of external magnetic field of built-in transformer substations. Electrical engineering \& electromechanics, 2020, no. 3, pp. 24-30. doi: 10.20998/2074-272X.2020.3.04.
V.Yu. Rozov ${ }^{1}$, Professor, Corresponding member of NAS of Ukraine,

K.D. Kundius ${ }^{1}$, Postgraduate Student,

D.Ye. Pelevin ${ }^{1}$, Candidate of Technical Science,

${ }^{1}$ State Institution «Institute of Technical Problems of Magnetism of the NAS of Ukraine»,

19, Industrialna Str., Kharkiv, 61106, Ukraine, e-mail: Rozov@nas.gov.ua, pelevindmitro@ukr.net 